\title{
Aspects of secondary bonding intramolecular interaction in organomercury and organochalcogen derivatives
}

\author{
SAGAR SHARMA, TAPASH CHAKRABORTY, KRITI SRIVASTAVA \\ and HARKESH B SINGH* \\ Department of Chemistry, Indian Institute of Technology Bombay, Powai, Mumbai 400076, India \\ e-mail: chhbsia@chem.iitb.ac.in
}

\begin{abstract}
Recent trends in the area of intramolecularly coordinated organomercury and organochalcogens derivatives are reviewed. Intramolecular coordination in organomercury derivatives facilitates the formation of mercurametallamacrocycle and leads to novel metal-metal interaction with closed shell ions. It also plays a key role in stabilizing telluroxanes as well as in the activation of chalcogen-carbon bonds.
\end{abstract}

Keywords. M-C bond cleavage; metallophilic; secondary bonding intramolecular interaction; organochalcogen; telluroxane; transmetallation.

\section{Introduction}

Secondary bonding interactions $\mathrm{E} \cdots \mathrm{X}(\mathrm{E}=\mathrm{Hg}, \mathrm{Se}$, $\mathrm{Te} ; \mathrm{X}=\mathrm{N}, \mathrm{O})$ involving mercury/chalcogen and heteroatoms continue to draw considerable attention due to their crucial role in various areas. The wellestablished applications of these interactions include; (i) template-free synthesis of mercuramacrocycle, ${ }^{1 \mathrm{a}}$ (ii) isolation of hypervalent organochalcogen compounds, (iii) chiral reagents for asymmetric synthesis, (iv) ligands for isolation of MOCVD precursors, and (v) glutathione peroxidase mimics. ${ }^{1 \mathrm{~b}}$ Our group has interest in different aspects of the chemistry of organomercury and organochalcogen compounds. In continuation of our work, we report here on some newer aspects of organomercury and organochalcogen chemistry where secondary bonding plays an important role in the template-free synthesis of mercurametallamacrocycles, stabilization of telluroxanes and the activation of $\mathrm{E}-\mathrm{C}$ bond $(\mathrm{E}=\mathrm{Se}, \mathrm{Te})$.

\section{Organomercury chemistry}

The chemistry of organomercury compounds is one of the well-studied areas in organometallic chemistry. The early development of organomercurial chemistry as compared to other organometallic compounds can be attributed to the high stability of organomercury compounds to air and moisture. Among the various applications of organomercurials, their use as

*For correspondence transmetallating agents ${ }^{2}$ for introducing various metals $\mathrm{Pd}(\mathrm{II}), \mathrm{Pt}(\mathrm{II}), \mathrm{Au}(\mathrm{I})$ and reagents for various functional group transformations in organic synthesis ${ }^{3}$ are ubiquitous. Multidentate organomercury compounds having Lewis acidic centers can act as electrophilic hosts ${ }^{4 \mathrm{a}}$ and hence are potential candidates to trap electronrich species as well as to build novel supramolecular architectures. One of the examples of such Lewis acidic behaviour was reported by Hawthorne and coworkers during the synthesis of a tetranuclear mercuracarborand which was isolated as a chloride complex (scheme 1). ${ }^{4 \mathrm{~b}}$

These mercuracarborands and their derivatives can readily form complexes with halide ions, nitrate ion and tetrahydrofuran. ${ }^{5}$ The Lewis acidity of organomercurials can be further improved by attaching suitable electronegative substituents such as fluoro group to the organic substrate. There are numerous examples in literature which document the use of fluoroorganomercurials as electrophilic hosts for anions and electron-rich neutral molecules. ${ }^{6}$ Trimeric perfluoroortho-phenylenemercury has been extensively studied in this respect. It not only binds with electron-rich substrates such as aldehydes, ketones, sulfoxides, sulfides but also with aromatic hydrocarbons, Nheterocycles and alkynes, etc. ${ }^{6}$
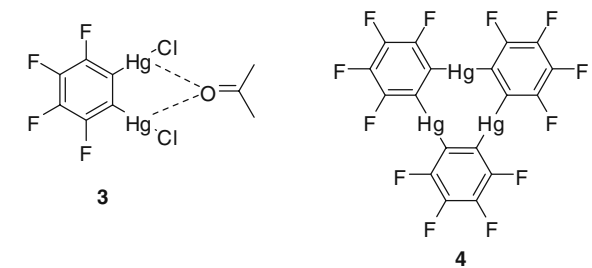


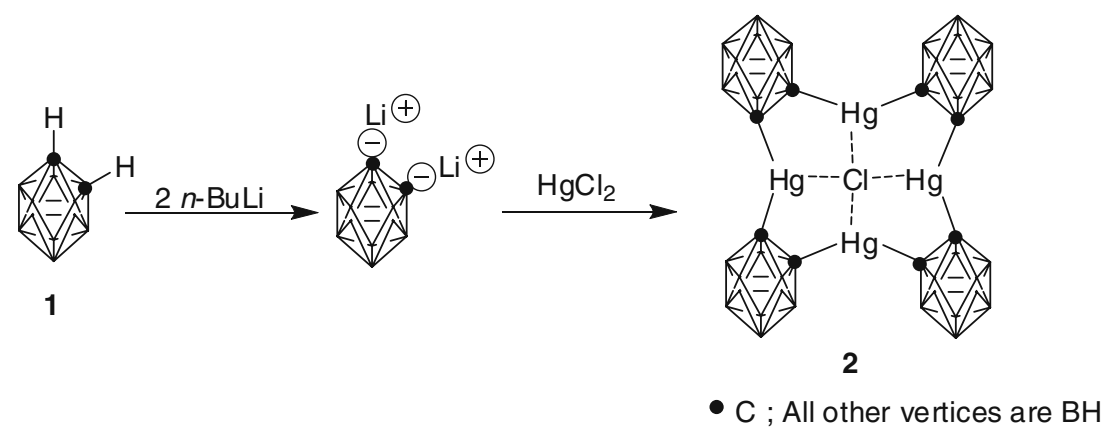

Scheme 1.

Another important feature of organomercury compounds is their ability to display metallophilic interactions. Several organomercurials exhibit short intermolecular $\mathrm{Hg} \cdot \mathrm{Hg}$ metallophilic interactions in the solid state and display unusual luminescent properties. ${ }^{7}$ These metallophilic interactions are attractive in nature and are quite common among closed-shell metal ions, such as gold(I), silver(I), copper(I). ${ }^{8} \mathrm{Hg}$ (II) being closed shell as well as isoelectronic with $\mathrm{Au}(\mathrm{I})$, is a potential candidate for displaying metallophilic interactions. Recent theoretical studies on these attractive interactions suggest that such interactions are mainly due to dispersive forces which are further augmented by relativistic effects for heavy elements. ${ }^{9}$ Although homometallic closed shell interactions are well-known in literature, heterometallic interactions involving three or more consecutive closed shell ions are relatively scarce. Catalano and co-workers have reported metal ion or atom encapsulation in metallacryptands, which are formed by self-assembly, resulting in different types of closed-shell $\mathrm{d}^{10} \cdots \mathrm{d}^{10}$ interactions. ${ }^{10}$

We have employed the secondary bonding E...O/N $(\mathrm{E}=\mathrm{Se}, \mathrm{Te})$ intramolecular interaction to synthesize a number of novel selenium and tellurium based macrocycles. ${ }^{11}$ The secondary interaction of chalcogens with nitrogen led to interesting reactivities of the macrocycles with different metal ions. We envisaged that the secondary bonding intramolecular interaction can also be employed for the synthesis of mercury based metallamacrocycles. The resulting metallamacrocycle that may form, will have Lewis acidic mercury as soft acid and imine nitrogen as Lewis base donors. Therefore, the resulting macrocycles will be able to coordinate to both 'hard' and soft 'base' ions. Apart from this, Lewis acidic organomercury could also prove suitable hosts for closed shell $\mathrm{d}^{10} / \mathrm{d}^{8}$ metal ions and may lead to heterometallic metal...metal systems. With this idea, the reaction of bis(o-formylphenyl)mercury with ethylenediamine was carried out which resulted in the formation of a novel 22-membered metallamacrocycle $(\mathbf{5})$ in high yield. ${ }^{1 \text { a }}$ The reaction can be viewed as a $[2+2]$ cycloaddition of aldehyde with the diamine. Secondary bonding $\mathrm{Hg}$... O intramolecular interaction present in the precursor bis(o-formylphenyl)mercury plays an important role in macrocyclization of aldehyde with the diamines. It is due to this secondary interaction that the reaction proceeds to completion even without the use of any template which is generally employed for the synthesis of macrocycles. In macrocycle 5, all the four nitrogens are interacting to mercury, with the distances of $2.750,2.760,2.777$ and $2.773 \AA$, thus exhibiting $\mathrm{Hg} \cdots \mathrm{N}$ interaction. Macrocycle 5, when treated with one equivalent of $\left[\mathrm{Cu}\left(\mathrm{CH}_{3} \mathrm{CN}\right)_{4}\right] \mathrm{ClO}_{4}$ in methanol, afforded an orange-yellow coloured complex 6. One of the important features of the $\mathrm{Cu}(\mathrm{I})$ complex 6 as evident from X-ray crystallography, was the presence of $\mathrm{Hg} \cdot \mathrm{Cu} \cdot \mathrm{CHg}$ interaction. The intramolecular $\mathrm{Cu} \cdot \mathrm{Hg}$ interatomic distances of $2.921 \AA$ and $2.919 \AA$ in 6 are much shorter than the sum of the van der Waals radii of the copper and mercury atoms $\left(r_{\mathrm{vwd}}=1.40\right.$ and $1.75 \AA$, respectively). The $\mathrm{Cu}(\mathrm{I})$ center is coordinated to all four nitrogen atoms as well as to the two mercury atoms to give a distorted octahedral geometry. Crystal packing of $\mathbf{6}$ revealed that, the cations of $\mathbf{6}$ are linked by a $\mathrm{Hg} \cdot . \mathrm{Hg}$ intermolecular interaction $(\mathrm{Hg} \cdots \mathrm{Hg} 3.20 \AA)$ to give a chain of six $\mathrm{d}^{10}$ ions.

Interestingly, the treatment of ligand $\mathbf{5}$ with $\mathrm{Cu}\left(\mathrm{OCOCH}_{3}\right)_{2}$, followed by an excess of ammonium hexafluorophosphate gave the $\mathrm{Cu}(\mathrm{I})$ complex 7 with $\mathrm{PF}_{6}^{-}$as the counter ion (scheme 2) instead of expected $\mathrm{Cu}$ (II) complex. ${ }^{12}$ The $\mathrm{Cu}(\mathrm{I})$ complexes were found to be luminescent at $77 \mathrm{~K}$ as well as at 


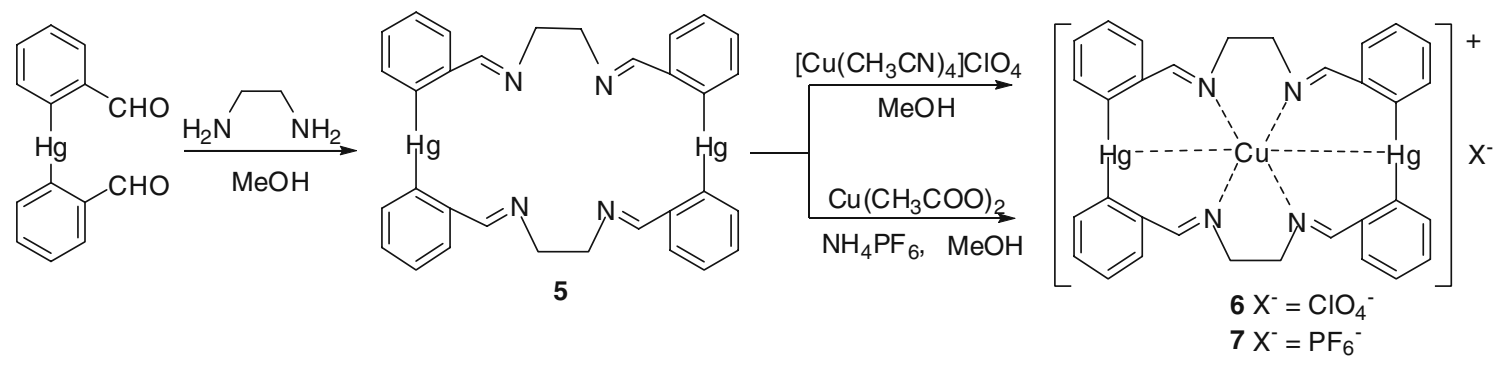

Scheme 2.
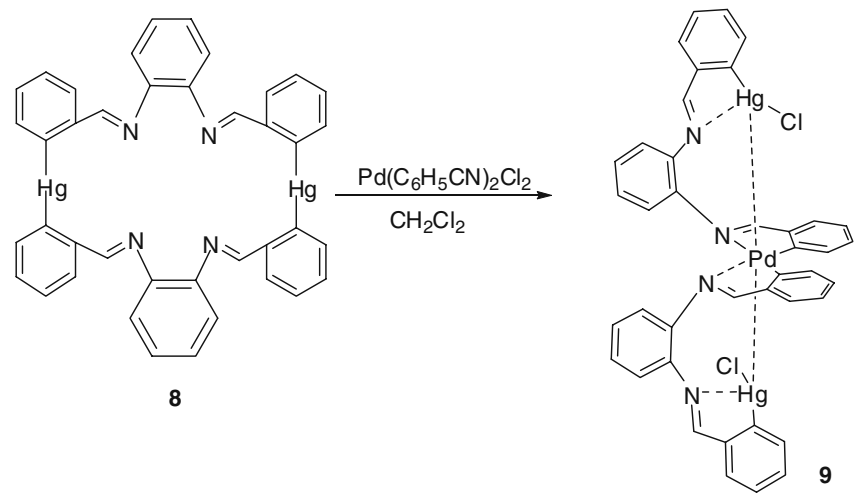

Scheme 3.

room temperature in acetonitrile solution. The reaction of mercuramacrocycles with other $\mathrm{d}^{10}$ ions have also been explored. The reaction of ligand $\mathbf{5}$ with $\mathrm{AgClO}_{4}$ afforded $\left([\mathbf{5} \cdot \mathrm{Ag}] \mathrm{ClO}_{4}\right)$ complex which exhibits distorted octahedral geometry around $\mathrm{Ag}$ as well as $\mathrm{Hg} \cdots \mathrm{Ag} \cdots \mathrm{Hg}$ interaction. Similar, attempted coordination of $\mathrm{Hg}^{\mathrm{II}}$ with 5 leads to facile cleavage of the ring and entrapment of a hydroxide ion. ${ }^{1 \mathrm{a}}$

On the other hand, the reaction of macrocycle 8 with an equimolar amount of $\left[\mathrm{PdCl}_{2}(\mathrm{PhCN})_{2}\right]$ leads to transmetallation of the aryl group from mercury to palladium and affords a trimetallic complex 9 containing two mercury and one palladium (scheme 3 ). ${ }^{13}$ The facile transmetallation of the aryl group from mercury to palladium has taken precedence over coordination by nitrogen/mercury, and results in the formation of cyclometallated palladium with cis disposition of the aryl groups. The two imino nitrogen coordinated to palladium are also in cis geometry with $\mathrm{N} \cdots \mathrm{Pd} \cdots \mathrm{N}$ bond angle being $103.25(7)^{\circ}$. It is observed that the geometry around central palladium atom is deviated from the square planar geometry with the diagonal angles N-Pd$\mathrm{C}$ angles being $165.27(9)^{\circ}$ and $164.31(9)^{\circ}$. The strong interaction of $\mathrm{Hg}$ with one of the imino nitrogen as well as with palladium is also responsible for deviation of $\mathrm{Cl}-\mathrm{Hg}-\mathrm{C}$ angles from linearity which in this case is $165.58(7)^{\circ}$ and $169.13(7)^{\circ}$. The complex has $\mathrm{Hg} \cdots \mathrm{Pd}$ distances of 3.1020(3) $\AA$ and 3.2337(3) $\AA$, which are significantly less than the sum of the van der Waals radii of $\mathrm{Hg}$ and $\mathrm{Pd}\left(\mathrm{r}_{\mathrm{vwd}}=1.75\right.$ and $1.63 \AA$, respectively) and hence display intramolecular $\mathrm{Hg}^{\mathrm{II}}$... $\mathrm{Pd}^{\mathrm{II}} . . . \mathrm{Hg}^{\mathrm{II}}$ interaction. The coordination of nitrogen to mercury atoms makes the groove around mercury non-linear, the $\mathrm{Hg}-\mathrm{Pd}-\mathrm{Hg}$ angle being $162.898(7)^{\circ}$. It is noteworthy that Gabbai and co-workers have reported intermolecular $\mathrm{Pd}(\mathrm{II}) \cdots \mathrm{Hg}(\mathrm{II}) \cdots \mathrm{Pd}(\mathrm{II})$ closed-shell interaction, which in fact is reversal of the $\mathrm{Hg}^{\mathrm{II}} \cdots \mathrm{Pd}^{\mathrm{II}} \cdots \mathrm{Hg}^{\mathrm{II}}$ system. ${ }^{14}$

DFT calculations on the crystal geometry confirmed the presence of $\mathrm{Hg}^{\mathrm{II}} \ldots \mathrm{Pd}^{\mathrm{II}} \ldots \mathrm{Hg}^{\mathrm{II}}$ interaction with location of the bond critical points (bcp) between $\mathrm{Hg} \ldots \mathrm{Pd}$ bonds. The NBO analysis revealed the origin of the $\mathrm{Hg} \cdot \cdots \mathrm{Pd} \cdots \mathrm{Hg}$ interaction to (i) donation of electron density from the palladium $4 \mathrm{~d}$ orbital to the antibonding $\sigma^{*}$ orbital of the $\mathrm{Hg}-\mathrm{C}$ bond and (ii) donation from the $\sigma$ orbital of the $\mathrm{Pd}-\mathrm{C}$ bond to the antibonding $\sigma^{*}$ orbital 
of the $\mathrm{Hg}-\mathrm{C}$ bond. Complex 9 is weakly luminescent in solid state, and exhibits a macrocycle-8-based emission band at $530 \mathrm{~nm}\left(\lambda_{\mathrm{ex}}=477 \mathrm{~nm}\right)$.

\section{Organotellurium chemistry}

Organotellurium compounds have been known for their rich chemistry and are widely used in many areas such as electronic conductors, as reagent for organic synthesis, in metallurgy and in biochemistry. ${ }^{15}$ Tellurium compounds having oxygen atoms linked to them are known as oxotellurides. These oxotellurides are generally synthesized by hydrolysis reaction of organotellurium halides or by oxidizing organotellurides and ditellurides. Often these oxotelluride such as telluroxides, tellurinic acid, tellurinic anhydride, tellurone and tellurium oxy-bromides are used as catalysts in organic synthesis as well as in organometallic reactions as oxygen carrier. ${ }^{16}$

Diorganotellurium oxides, $\mathrm{R}_{2} \mathrm{TeO}(\mathrm{R}=$ alkyl, aryl), have been known since early 20th century and are usually prepared by alkaline hydrolysis of diorganotellurium dihalides. ${ }^{17}$ Surprisingly, the structure of first well-characterized diphenyltelluroxide $\left(\mathrm{Ph}_{2} \mathrm{TeO}\right)$ $\mathbf{1 0}$ was reported in late 90's by Alcock and Harrison. ${ }^{18}$ The solid state structure suggested that the two crystallographically independent units are linked together by short secondary Te-O interaction $(2.55(1) \AA)$ giving rise to a dimeric structure. Later on Naumann et al. ${ }^{19}$ and Klapötke et al. ${ }^{20}$ independently published the crystal structure of $\left(\mathrm{C}_{6} \mathrm{~F}_{5}\right)_{2} \mathrm{TeO}$ (as toluene solvate) and (as $\mathrm{CH}_{2} \mathrm{Cl}_{2}$ and benzene solvates) respectively. The solid state structure for this compound was also found to be similar to the former one with relatively shorter secondary Te...O interaction (2.200(1) ^). Recently Beckmann et al. have reported the structure of ( $p$ $\left.\mathrm{MeOC}_{6} \mathrm{H}_{4}\right)_{2} \mathrm{TeO}$ having polymeric arrangement of $\mathrm{Te}-\mathrm{O}$ bond in a zig-zag confirmation rather than the usual dimeric form. ${ }^{21}$<smiles>O=[Te](O[Te](=O)(c1ccccc1)c1ccccc1)(c1ccccc1)c1ccccc1</smiles>

Though the use of telluroxide as mild oxidizing agent in organic chemistry and as oxygen transfer reagent in organometallic chemistry is well-known, ${ }^{16}$ recently there is a considerable interest because of its usage in various fields. For example, Kobayashi et al. have isolated oligotelluroxane $\mathbf{1 1}$ by the reaction of telluroxide with cationic ditelluroxanes. ${ }^{22}$ The ditelluroxides have also been successfully used to isolate macrocyclic multi-telluranes $\mathbf{1 2}$ by the reaction of cationic ditelluroxane with sodium phthalate. ${ }^{23}$ Beckmann and coworkers have demonstrated that solutions containing ditert-butyltin oxide and di- $p$-anisyltellurium oxide readily absorb gaseous $\mathrm{CO}_{2}$ to produce a molecular tellurastannoxane. ${ }^{24}$ In a recent study it has been found that telluroxide compounds exhibit hydrolysis capacity and can be used as hydrolase mimic. ${ }^{25}$

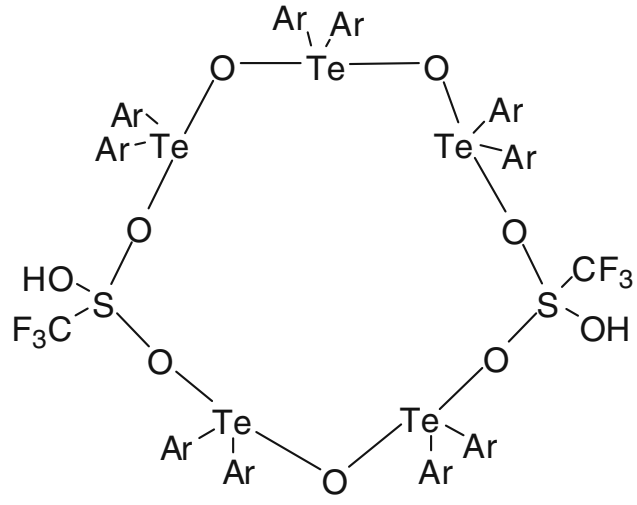

11

$$
\mathrm{Ar}=\mathrm{MeC}_{6} \mathrm{H}_{5}
$$


In contrast to the hydrolysis products of organotellurium dihalides whose structures and reactivities are now well-understood, the hydrolysis products of aryltellurium trihalides are not well-characterized. Initial studies on hydrolysis reactions revealed that the hydrolysis of phenyl and substituted phenyl trihalides in water results in the formation of partial hydrolysed product such as $\mathrm{RTe}(\mathrm{O}) \mathrm{X}\left(\mathrm{R}=\mathrm{C}_{6} \mathrm{H}_{5}, p\right.$-EtOC $\left.{ }_{6} \mathrm{H}_{4}\right)(\mathrm{X}=\mathrm{Cl}$ and $\mathrm{Br}$ ). Whereas, hydrolysis under alkaline condition results in the formation of $\mathrm{RTe}(\mathrm{OH})_{3}, \mathrm{RTeO}(\mathrm{OH})$ and $\mathrm{R}_{2} \mathrm{Te}_{2} \mathrm{O}_{3}$. It was observed that $\left(p-\mathrm{EtOC}_{6} \mathrm{H}_{4}\right)_{2} \mathrm{TeO}(\mathrm{OH})$ upon treatment with dilute acid can also afford completely hydrolysed product $\left(p-\mathrm{EtOC}_{6} \mathrm{H}_{4}\right)_{2} \mathrm{Te}_{2} \mathrm{O}_{3}$. They further concluded that the iodo-derivative is difficult to hydrolyse under normal condition. ${ }^{26}$ Later on Comasseto et al. found that alkaline hydrolysis when carried out in the presence of phase transfer catalyst also results in the formation of tellurinic anhydride, $\mathrm{R}_{2} \mathrm{Te}_{2} \mathrm{O}_{3}\left(\mathrm{R}=\mathrm{C}_{6} \mathrm{H}_{5}, p-\mathrm{EtOC}_{6} \mathrm{H}_{4}\right){ }^{27}$

Beckmann and co-workers have demonstrated the synthesis of $\mathrm{RTe}(\mathrm{O}) \mathrm{OH}(\mathbf{1 3})$ and $\mathrm{RTe}(\mathrm{O}) \mathrm{Cl}$ (14) by kinetically controlled hydrolysis of 2,6$\mathrm{Mes}_{2} \mathrm{C}_{6} \mathrm{H}_{3} \mathrm{TeCl}_{3}$ in two layer system of toluene and $0.5 \mathrm{M}$ sodium hydroxide solution. ${ }^{28}$ The molecular structures of $\mathbf{1 3}$ and $\mathbf{1 4}$ comprise of asymmetric fourmember $\mathrm{Te}_{2} \mathrm{O}_{2}$ ring with exocyclic $\mathrm{OH}$ and $\mathrm{Cl}$ group respectively. The geometry around tellurium has been described as distorted trigonal-bipyramidal. Due to the presence of bulky substituent, no further aggregation was observed. Giolando and co-workers obtained an anionic $\mathrm{Te}-\mathrm{O}$ cluster having general formula of $\quad\left[\mathrm{Li}(\mathrm{THF})_{4}\right]\left[\left\{\left(\mathrm{Pr}^{\mathrm{i} T e}\right)_{12} \mathrm{O}_{16} \mathrm{Br}_{4}\{\mathrm{Li}(\mathrm{THF}) \mathrm{Br}\}_{4}\right\} \mathrm{Br}\right]$. 2 THF. $^{29}$ This air sensitive cluster was obtained serendipitously while preparing isopropyl hex-1-ynyl telluride and was formally claimed as the condensation product of organotellurium trihydroxide.

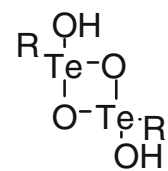

13

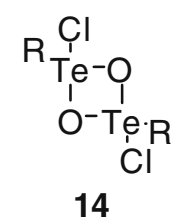

14

$$
\mathrm{R}=2,6-\mathrm{Mes}_{2} \mathrm{C}_{6} \mathrm{H}_{3}
$$

From the above discussion it is quite clear that most of the studies on the hydrolysis reaction have been performed using bulky ligands or substituted benzene and it was found that the hydrolysed products thus obtained are either dimeric or polymeric (vide infra). It is well-known that intramolecular coordination helps in the stabilization and isolation of monomeric and labile

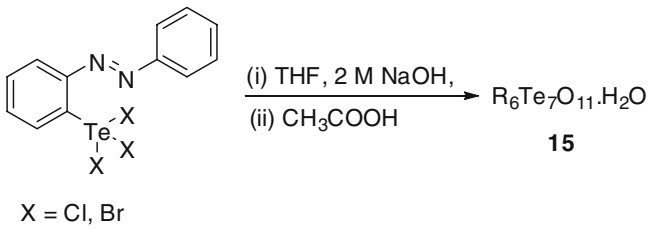

Scheme 4.

chalcogen species. Our group has a long standing interest in exploring the role of intramolecular coordination in stabilizing rather unstable organochalcogen species. ${ }^{30}$ Utilizing the concept we and others have been successful in the isolation of several labile organochalocogen derivatives. ${ }^{31}$ There have been no studies on the hydrolysis reaction of intramolecularly coordinated organotellurium halides, we thought of investigating it by using ligand which has potential $\mathrm{N}$-donor atom. The remarkable stability of 2phenylazophenyl under alkaline and acidic condition and its unique donor property inspired us to study the hydrolysis reaction of its halides $(\mathrm{RTeCl}$, $\mathrm{R}_{2} \mathrm{TeCl}_{2}, \mathrm{RTeCl}_{3}, \mathrm{RTeBr}_{3}$ ). Our main target was to isolate intramolecularly stabilized well-defined monomeric or condensed organo-oxotellurides using 2-phenylazophenyl. However, the alkaline hydrolysis of bis(2-phenylazophenyl-C, $N^{\prime}$ )tellurium(IV) dichloride gave bis(2-phenylazophenyl-C, $N^{\prime}$ )tellurium(IV) oxide which has secondary Te...O interaction giving rise to dimeric structure. The hydrolysis of (2phenylazophenyl-C, $N$ ')tellurium(IV) trichloride under reflux condition resulted in the isolation of co-crystal of monomeric tellurinic acid and its sodium salt. Similarly, when we hydrolysed (2-phenylazophenylC, $N^{\prime}$ )tellurium(IV) trihalide a novel heptatellurium covalent cluster 15 having Te-O linkage was obtained (scheme 4). ${ }^{32}$ This molecule has several unique features e.g., all the peripheral tellurium and oxygen atoms are linked together in a boat shape conformation, molecule has three types of tellurium viz. 3-coordinated, 4coordinated and 5-coordinated and all are in the same oxidation state.

\section{Cleavage reactions of organochalcogens by transition metals}

Activation and cleavage of the Se-Se, Te-Te, C-Se and $\mathrm{C}-\mathrm{Te}$ bonds by transition metals (viz. Pd, Pt, Hg, Rh, etc.) is an important feature of the coordination chemistry of organoselenium and organotellurium ligands. 
A detailed understanding of the coordination chemistry of organoselenium and organotellurium ligands is essential to reveal the mechanistic details of the various catalytic processes in which these are involved. In this context some leading trends observed in the synthetic application of heavier organochalcogens include; (i) use of diorganoselenides and diorganotellurides as substrates in catalytic coupling reactions to form $\mathrm{C}-\mathrm{C}$ bonds by activating $\mathrm{C}-\mathrm{Se}$ or $\mathrm{C}-\mathrm{Te}$ bonds, (ii) use of diorgano diselenides to undergo addition to multiple bonds, especially to $-\mathrm{C} \equiv \mathrm{C}-$ catalytically, (iii) synthesizing symmetrical and unsymmetrical diorganoselenides and tellurides catalytically from electrophilic substrates incorporating various functionalities and $\mathrm{R}_{2} \mathrm{E}_{2}(\mathrm{E}=\mathrm{Se}, \mathrm{Te})$ as nucleophilic precursor and (iv) use of organoselenium compounds as ligands in various catalytic organic transformations.

Organoselenides were used in Kumada coupling reactions as source of aryl, vinyl and allyl functions in as early as 1980 by Takei and co-workers. ${ }^{33}$ However, the use of organoselenides in coupling reactions has not received much attention thereafter. Organotellurides have also been used in catalytic carbon-carbon bond formation as aryl or vinyl synthons. Uemura and co-workers reported palladium-catalysed FujiwaraHeck cross coupling reactions between organic tellurides and alkenes. ${ }^{34}$ Palladium catalysed coupling of vinylic tellurides for the synthesis of conjugated enyne and enediyne has been systematically studied by Zeni and co-workers employing Suzuki, Sonogashira and Negishi coupling methodologies. ${ }^{35}$ More recently, Stefani and co-workers have reported Suzuki-Miyaura cross-coupling reactions of aryl tellurides with potassium aryltrifluoroborate salts catalysed by $\mathrm{Pd}(0)$ complexes. ${ }^{36}$ The key step of the coupling reactions was proposed to be the migration of an organic moiety from Te to Pd in the organotelluride-Pd(II) complex to generate the organopalladium intermediate. The proposed mechanism has been supported by 'fishing' and characterization of intermediates by ESI-MS and ESI-MS/MS experiments. ${ }^{37}$

Vinyl selenides are an important class of compounds which can conveniently prepared by addition of $\mathrm{R}_{2} \mathrm{Se}_{2}$ or $\mathrm{RSeH}$ to alkynes catalysed by transition metals like $\mathrm{Pd}, \mathrm{Ni}$ or Rh. Beletskaya and co-workers have outlined the achievements and challenges in this area in a recent review. ${ }^{38}$

Another important recent trend where activation of E-E bond is relevant is the synthesis of diorganochalcogenides from diorganodichalcogenides employing various catalytic strategies. For example, employing a

bimetallic catalyst system consisting of hydrated $\mathrm{CuCl}_{2}$ and $\mathrm{SnCl}_{2}$ a range of unsymmetrical selenides have been prepared by Roy and co-workers. ${ }^{39 a}$ Other variants include $\mathrm{La} / \mathrm{I}_{2},{ }^{39 \mathrm{~b}} \mathrm{CuI} / \mathrm{Mg}$-bipy, ${ }^{39 \mathrm{c}} \mathrm{RuCl}_{3} / \mathrm{Zn},{ }^{39 \mathrm{~d}}$ $\mathrm{Pd}\left(\mathrm{PPh}_{3}\right)_{4},{ }^{39 \mathrm{e}} \mathrm{RhCl}\left(\mathrm{PPh}_{3}\right)_{3} / \mathrm{H}_{2},{ }^{39 \mathrm{f}} \mathrm{InBr}_{3} / \mathrm{Zn}$, ${ }^{39 \mathrm{~g}}$, etc.

Use of heavier chalcogens as ligands for catalysts in the coupling reactions has high potential and recently it has been reported by Yao and co-workers that selenium ligated palladium complexes act as highly active and efficient catalysts for the Heck reaction. ${ }^{40}$ Szabó and co-workers ${ }^{41}$ and Yao and co-workers ${ }^{42}$ have demonstrated the utility of SeCSe-Pd(II) pincer complex in the catalytic phenylselenylation of organohalides and allylation of aldehydes respectively.

The $\mathrm{C}-\mathrm{Se}$ bond is inherently stronger than the $\mathrm{C}-$ Te bond and activation and cleavage of the former is not very common. The activation of the $\mathrm{C}-\mathrm{Se}$ bond in a vinyl selenide by a $\operatorname{Pt}(0)$ complex has been reported by Kambe and co-workers. ${ }^{43}$ In a study involving addition of diaryl dichalcogenides to terminal alkynes under microwave irradiation, Beletskaya and co-workers also identified a process in which $\mathrm{C}-\mathrm{Se}$ bond was activated and cleaved to generate monoselenide from diselenide by $\mathrm{Pd}(\mathrm{OAc})_{2} /$ phosphine catalytic system in the absence of alkyne. ${ }^{44}$ Using quantum mechanical calculations they have shown that both mononuclear $\left[\mathrm{Pd}(\mathrm{SePh})_{2}\left(\mathrm{PPh}_{3}\right)_{2}\right]$ and dinuclear palladium complexes $\left[\mathrm{Pd}_{2}(\mathrm{SePh})_{4}\left(\mathrm{PPh}_{3}\right)_{2}\right]$ can catalyse the $\mathrm{C}-\mathrm{Se}$ bond cleavage reaction and the reactions involving dinuclear complexes can proceed with smaller energy requirements, which is due to stabilization of the bridging selenium ligands.

The $\mathrm{C}-\mathrm{Te}$ bond cleavage has received current interest due to its relevance in catalysis. McWhinnie and co-workers and Levason and co-workers observed the lability and cleavage of the $\mathrm{C}-\mathrm{Te}$ bond by transition metal ions much earlier. ${ }^{45}$ The telluroether ligand $\mathbf{1 6}$ on reaction with $\mathrm{PtCl}_{2}$ underwent a cleavage of the butyl group and the $\mathrm{C}-\mathrm{Te}$ cleavage was monitored by NMR studies. ${ }^{45}$ a The cleavage of a methyl group from a telluroether complex of palladium, $\mathbf{1 7}$ on heating has been reported by Levason and co-workers. ${ }^{45 b}$

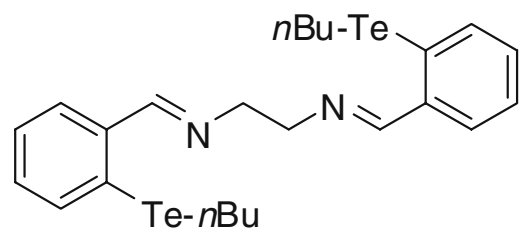

16<smiles>C[Te]1P[Te]c2ccccc21</smiles>

17 
The cleavage of $\mathrm{C}-\mathrm{Te}$ is facilitated by the strong $\mathrm{N} \rightarrow \mathrm{Te}$ intramolecular interaction, which involves donation of a nitrogen lone pair to the $\sigma^{*}$ orbital of the trans $\mathrm{C}-\mathrm{Te}$ bond. ${ }^{46}$ A facile $\mathrm{C}-\mathrm{Te}$ bond cleavage and transmetallation in the reaction of the 22- membered azamacrocyclic ligand $\mathbf{1 8}$ with $\mathrm{HgCl}_{2}$ and $\mathrm{Pt}(\mathrm{COD}) \mathrm{Cl}_{2}$ have been reported by our group. ${ }^{47} \mathrm{We}$ have also reported the facile cleavage of the $\mathrm{C}-\mathrm{Te}$ bond in bis[2-(4,4-dimethyl-2-oxazolinyl)phenyl] telluride 19 on reaction with $\mathrm{HgCl}_{2} .{ }^{48}$<smiles>C(=NCCN=Cc1ccccc1[Te]c1ccccc1C=NCCN=Cc1ccccc1[Te]c1ccccc1)c1ccccc1</smiles>

18<smiles>CC1(C)COC(c2ccccc2[Te]c2ccccc2C2=NC(C)(C)CO2)=N1</smiles>

19
In contrast to the activation and cleavage reactions of $\mathrm{R}_{2} \mathrm{E}_{2}(\mathrm{E}=\mathrm{Se}, \mathrm{Te})$ by $\operatorname{Pd}(0) / \mathrm{Pt}(0)$ complexes, there are very few examples of cleavage reactions of $\mathrm{R}_{2} \mathrm{E}_{2}$ by $\mathrm{Pd}(\mathrm{II}) .{ }^{49}$ Very recently Singh et al. reported on the cleavage reactions of a series of a related chiral and achiral multidentate selenium and tellurium ligands 20-24 with Pd(II) complexes. ${ }^{49}$<smiles>CN(C)c1ccccc1S(=O)(=O)O</smiles>

20<smiles>CN(C)Cc1ccccc1[Te]c1ccccc1CN</smiles>

23<smiles>CN(C)C(c1ccccc1)[S+](=O)[O-]</smiles>

21<smiles>C[C@H](N=Cc1ccccc1[Te]c1ccccc1C=N[C@@H](C)c1ccccc1)c1ccccc1</smiles><smiles>CN(C)Cc1ccccc1[18O]</smiles>

22
The excellent palladium complex could not be isola ted from the reaction of the diselenide $\mathbf{2 0}$ with $\mathrm{Pd}(\mathrm{COD})$ $\mathrm{Cl}_{2}$ and the isolated fraction was characterized as $\mathrm{RSeCl}$. Diselenide 21 provided a selenolate bridged dinuclear complex 25 on reaction with Pd(II). Ditelluride 22 underwent cleavage of the $\mathrm{Te}-\mathrm{Te}$ bond on reaction with $\mathrm{Pd}(\mathrm{II})$ and a similar tellurolate bridged dinuclear complex 26 was obtained. In addition to that, a dimeric chloro-bridged telluranyl chloride, $(\mathrm{RTeCl})_{2}$ was isolated and characterized. It was argued that the $\mathrm{R}_{2} \mathrm{E}_{2}$ ligands underwent a formal self-redox reaction on treatment with Pd(II) salts. Tellurides $\mathbf{2 3}$ and $\mathbf{2 4}$ afforded transmetallated dinuclear Pd(II) complexes $\mathbf{2 7}$ and $\mathbf{2 8}$ along with the dimeric telluranyl chloride, $(\mathrm{RTeCl})_{2}$. 


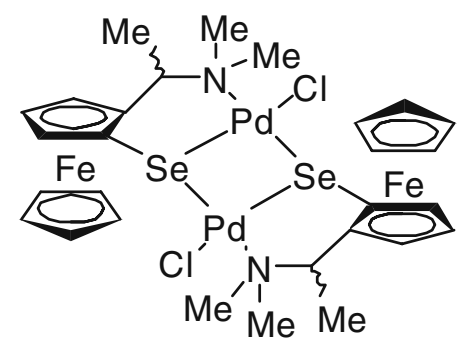

25<smiles>C[C@@H](N=Cc1ccccc1P(Cl)[Te][Te](Cl)(Cl)c1ccccc1C=N[C@H](C)c1ccccc1)c1ccccc1</smiles>

27

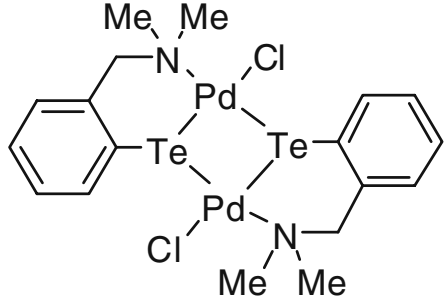

26<smiles>CN(C)Cc1ccccc1P(Cl)O[Te]P(Cl)c1ccccc1CN</smiles>

28
Acetato-bridged dinuclear palladacycle obtained from $\mathrm{Pd}(\mathrm{OAc})_{2}$ and $\mathrm{P}(\mathrm{o} \text {-tol })_{3}$, the so-called Hermann palladacycle is well-known in homogeneous catalysis as excellent catalyst for the Heck and Suzuki coupling reactions. ${ }^{50} \mathrm{We}$ wondered whether a similar palladacycle could be synthesized from $\mathrm{E}(o \text {-tol })_{2},(\mathrm{E}=\mathrm{Se}, \mathrm{Te})$
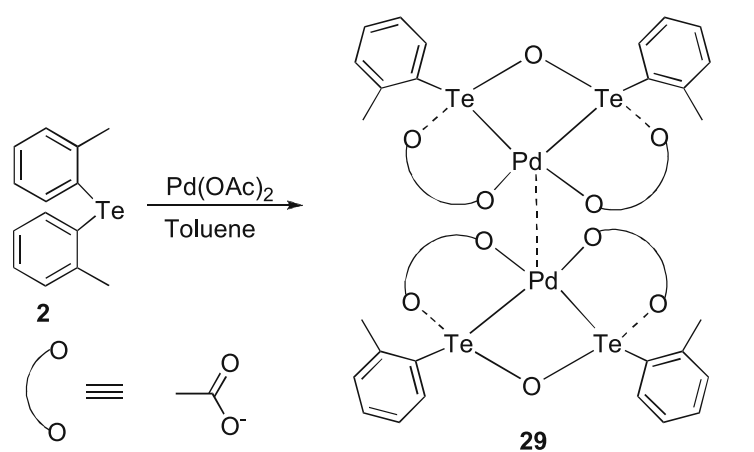

29

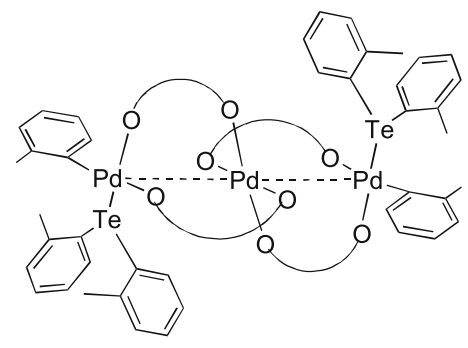

30
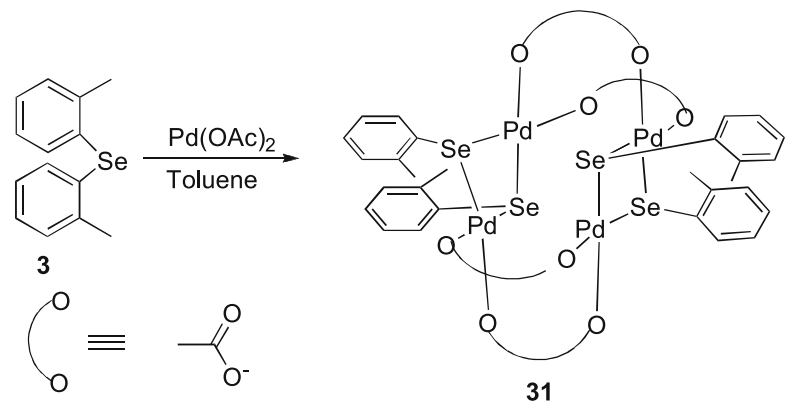

Scheme 5. 
on reaction with $\mathrm{Pd}(\mathrm{OAc})_{2}$. However, some unexpected interesting results were obtained in the reactions (scheme 5). ${ }^{51}$ Reaction between bis(o-tolyl)telluride and palladium acetate in toluene provided a novel oxygen-bridged hexanuclear (29) and a linear trinuclear (30) palladium complex. Bis(o-tolyl)selenide provided another interesting selenolate and acetate bridged tetranuclear palladium complex (31).

\section{References}

1. (a) Patel U, Sharma S, Singh H B, Dey S, Jain V K, Wolmershäuser G and Butcher R J 2010 Organometallics 29 4265; (b) Mukherjee A J, Zade S S, Singh H B and Sunoj R B 2010 Chem. Rev. 1104357 and references therein

2. (a) Vicente J, Arcas A, Gálvez-López M D, Jones P G and Bautista D 2009 Organometallics 28 3501; (b) Spencer A 1987 Comprehensive coordination chemistry (eds) G Wilkinson, R Gillard and J A McCleverty (Oxford: Pergamon Press) vol 6; (c) Carruthers W 1982 Comprehensive organometallic chemistry (Oxford: Pergamon Press) vol 7

3. Larock R C 1985 Organomercury compounds in organic synthesis (New York: Springer-Verlag)

4. (a) Wuest J D 1999 Acc. Chem. Res. 32 81; (b) Yang X, Knobler C B and Hawthorne M F 1991 Angew. Chem. Int. Ed. 301507

5. Bayer M J, Jalisatgi S S, Smart B, Herzog A, Knobler C B and Hawthorne M F 2004 Angew. Chem. Int. Ed. 43 1854 and references therein

6. Taylor T J, Burress C N and Gabbaï F P 2007 Organometallics 265252 and references therein

7. King J B, Haneline M R, Tsunoda M and Gabbaï F P 2002 J. Am. Chem. Soc. 1249350

8. (a) Pyykkö P 1997 Chem. Rev. 97 597; (b) Pyykkö P 2004 Angew. Chem. Int. Ed. $\mathbf{4 3} 4412$

9. Pyykkö P 2005 Inorg. Chim. Acta $\mathbf{3 5 8} 4113$

10. Catalano V J, Bennett B L, Malwitz M A, Yson R L, Kar $\mathrm{H}$ M, Muratidis S and Horner S J 2003 Comments Inorg. Chem. 24 39; (b) Catalano V J and Malwitz M A 2004 J. Am. Chem. Soc. 1266560

11. (a) Panda A, Menon S C, Singh H B, Morley C P, Bachman R, Cocker T M and Butcher R J 2005 Eur. J. Inorg. Chem. 1114; (b) Panda S, Zade S S, Singh H B and Butcher R J 2006 Eur. J. Inorg. Chem. 172

12. Patel U, Singh H B and Wolmershäuser G 2005 Angew. Chem. Int. Ed. 441715

13. Sharma S, Baligar R S, Singh H B and Butcher R J 2009 Angew. Chem. Int. Ed. 481987

14. Kim M, Taylor T J and Gabbaï F P 2008 J. Am. Chem. Soc. 1306332

15. (a) Sandman D J, Stark J C and Foxman B M 1982 Organometallics 1 739; (b) Hiiro T, Morita Y, Inoue T, Kambe N, Ogawa A, Ryu I and Sonoda N $1990 \mathrm{~J}$.
Am. Chem. Soc. 112 455; (c) Engman L, Stern D and Stenberg B 1996 J. Appl. Polym. Sci. 59 1365; (d) Avilov D V, Malusare M G, Arslancan E and Dittmer D C 2004 Org. Lett. 6 2225; (e) Landis C A, Payne M M, Eaton D L and Anthony J E 2004 J. Am. Chem. Soc. 126 1338; (f) Mutoh Y, Murai T and Yamago S 2004 J. Am. Chem. Soc. 12616696

16. (a) Ley S V, Meerholz C A and Barton D H R 1980 Tetrahedron Lett. 21 1785; (b) Akiba M, Lakshmikantham M V, Jen K-Y and Cava M P 1984 J. Org. Chem. 49 4819; (c) Barton D H R, Finet J-P and Thomas M 1986 Tetrahedron 42 2319; (d) Huang Z-Z and Tang Y $2002 \mathrm{~J}$. Org. Chem. 67 5320; (e) Oba M, Okada Y, Nishiyama K, Sihmada S and Ando W 2008 Chem. Commun. 5378; (f) Xue M, Gao Y C, Shen J K, Shi Q Z and Basolo F 1993 Inorg. Chim. Acta 207 207; (g) Liu X, Gao Y C, Su Z X, Wang Y Y and Shi Q Z 1999 Trans. Met. Chem. 24 666; (h) Song L C, Li Q S, Hu Q M and Dong Y B $2001 J$. Organomet. Chem. 619194

17. (a) Lederer K 1912 Ann. Chem. 391 326; (b) Lederer K 1916 Chem. Ber. 49 1076; (c) Bergman J 1972 Tetrahedron 28 3323; (d) Irgolic K I 1974 The organic chemistry of tellurium (New York: Gordon and Breach); (e) Morgan G T and Kellett R E 1926 J. Chem. Soc. 1080

18. Alcock N W and Harrison W D 1982 J. Chem. Soc., Dalton Trans. 709

19. Naumann D, Tyrra W, Herrmann R, Pantenburg I and Wickleder M S 2002 Z. Anorg. Allg. Chem. 628833

20. Klapötke T M, Krumm B, Mayer P, Piotrowski H and Ruscitti O P 2002 Z. Naturforsch. B57 145

21. Beckmann J, Dakternieks D, Duthie A, Ribot F, Schürmann M and Lewcenko N A 2003 Organometallics 223257

22. (a) Kobayashi K, Deguchi N, Takahashi O, Tanaka K, Horn E, Kikuchi O and Furukawa N 1999 Angew. Chem. Int. Ed. 38 1638; (b) Kobayashi K, Tanaka K, Izawa H, Arai Y and Furukawa N 2001 Chem. Eur. J. 74272

23. Kobayashi K, Izawa H, Yamaguchi K, Horn E and Furukawa N 2001 Chem. Commun. 1428

24. Beckmann J, Dakternieks D, Duthie A, Lewcenko N A and Mitchell C 2004 Angew. Chem. Int. Ed. 436683

25. Dong Z, Li X, Liang K, Mao S, Huang X, Yang B, Xu J, Liu J, Luo G and Shen J 2002 J. Org. Chem. 72606

26. (a) Thavornyutikarn P and McWhinnie W R $1973 J$. Organomet. Chem. 50135 and references therein; (b) Irgolic K J 1975 J. Organomet. Chem. 10391

27. Comasseto J V, Ferreira J T B and Fontanillas Val J A 1984 J. Organomet. Chem. 277261

28. Beckmann J, Finke P, Hesse M and Wettig B 2008 Angew. Chem. Int. Ed. 479982

29. Citeau H, Kirschbaum K, Conrad O and Giolando D M 2001 Chem. Commun. 2006

30. (a) Sudha N and Singh H B 1994 Coord. Chem. Rev. 135/136 469; (b) Mugesh G and Singh H B 2002 Acc. Chem. Res. 35 226; (c) Zade S S, Singh H B and Butcher R J 2004 Angew. Chem. Int. Ed. 434513

31. (a) Hamor T A, Al-Salim N, West A A and McWhinnie W R 1986 J. Organomet. Chem. 310 C5; (b) Kaur R, Singh H B and Butcher R J 1995 Organometallics 14 4755; (c) Poleschner H and Seppelt K 2004 Chem. Eur. 
J. 10 6565; (d) Klapötke T M, Krumm B and Polborn K 2004 J. Am. Chem. Soc. 126 710; (e) Kumar S, Kandasamy K, Singh H B, Wolmershäuser G and Butcher R J 2004 Organometallics 23 4199; (f) Wismach C, du Mont W-W, Jones P G, Ernst L, Papke U, Mugesh G, Kaim W, Wanner M and Becker K D 2004 Angew. Chem. Int. Ed. 43 3970; (g) Beckmann J, Bolsinger J and Duthie A 2009 Organometallics 28 4610

32. (a) Srivastava K, Sharma S, Singh H B, Singh U $\mathrm{P}$ and Butcher R J 2010 Chem. Commun. 46 1130; (b) Srivastava K, Shah P, Singh H B and Butcher R J 2011 Organometallics 30534

33. Okamura H, Miura M, Kosugi K and Takei H 1980 Tetrahedron Lett. 21, 87

34. Nishibayashi Y, Cho S C and Uemura S $1996 J$. Organomet. Chem. 507197

35. (a) Zeni G, Braga A L and Stefani H A 2003 Acc. Chem. Res. 36 731; (b) Zeni G, Ludtke D S, Panatieri R B and Braga A L 2006 Chem. Rev. 1032

36. Cella R, Cunha R L O R, Reis A E S, Pimenta D C, Klitzke C F and Stefani H A 2006 J. Org. Chem. 71244

37. Raminelli C, Prechtl M H G, Santos L S, Eberlin M N and Comasseto J V 2004 Organometallics 233990

38. Beletskaya I P and Ananikov V P 2007 Eur. J. Org. Chem. 3431

39. (a) Kundu A and Roy S 2000 Organometallics 19 105; (b) Nishino T, Okada M, Kuroki T, Watanabe T, Nishiyama Y and Sonoda N 2002 J. Org. Chem. 67 8696; (c) Taniguchi N and Onami T 2004 J. Org. Chem. 69 915; (d) Zhao X, Yu Z, Yan S, Wu S, Liu R, He W and Wang L 2005 J. Org. Chem. 70 7338; (e) Beletskaya I P, Sigeev A. S, Peregudov A S, Petrovskii
P V 2000 J. Organomet. Chem. 605 96; (f) Ajiki K, Hirano M and Tanaka K 2005 Org. Lett. 7 4193; (g) Braga A L, Schneider P H, Paixao M W and Deobald A M 2006 Tetrahedron Lett. 477195

40. Yao Q, Kinney E P and Zheng C 2004 Org. Lett. 62997

41. Wallner O A and Szabó K J 2005 J. Org. Chem. 709215

42. Yao Q and Sheets M 2006 J. Org. Chem. 715384

43. Kuniyasu $\mathrm{H}$, Kato $\mathrm{T}$, Inoue $\mathbf{M}$, Terao $\mathbf{J}$ and Kambe $\mathrm{N}$ 2006 J. Organomet. Chem. 6911873

44. Ananikov V P, Orlov N V and Beletskaya I P 2005 Russ. Chem. Bull. Int. Ed. $\mathbf{5 4} 576$

45. (a) Al-Salim N I and McWhinnie W R 1989 Polyhydron 8 2769; (b) Kemmitt T, Levason W, Spicer M D and Webster M 1990 Organometallics 91181

46. Tripathi S K, Patel U, Roy D, Sunoj R B, Singh H B, Wolmershäuser G and Butcher R J 2005 J. Org. Chem. $\mathbf{7 0} 9237$

47. (a) Menon S C, Singh H B, Patel R P and Kulshreshtha S K 1996 J. Chem. Soc., Dalton Trans. 1203; (b) Menon S C, Panda A, Singh H B and Butcher R J 2000 Chem. Commun. 43; (c) Panda S, Singh H B and Butcher R J 2004 Chem. Commun. 322

48. Apte S D, Zade S S, Singh H B and Butcher R J 2003 Organometallics 225473

49. Kaur R, Menon S C, Panda S, Singh H B, Patel R P and Butcher R J 2009 Organometallics 282363

50. Herrmann W A, Öfele K, Preysing D and Schneider S K 2003 J. Organomet. Chem. 687229

51. Chakraborty T, Singh H B and Butcher R J Reactions of Di(o-tolyl) Telluride and -Selenide with Palladium Acetate: Isolation of a Novel Trinuclear ì2-oxo Palladium Complex and Related Trinuclear and Tetranuclear Palladium Complexes, (unpublished results) 